\title{
Erratum
}

\section{Messy Grand Narrative or Analytical Blind Spot? When Speaking of Neoliberalism}

\section{Sean Phelan}

Comparative European Politics (2007) 5, 463. doi:10.1057/palgrave.cep.6110125

Correction to: Comparative European Politics (2007) 3, 328-338, doi:10.1057/Palgrave.cep.6110111

The editors and publishers would like to apologize to Sean Phelan for an unfortunate error in the transcription of his article. The text on page 332 of his article was misrepresented as:

'Perhaps may be overinflates. Yet to observe the point the ideological importance of the utopian element in the first place...'

This should have read

'Perhaps. Yet to observe the point maybe overinflates the ideological importance of the utopian element in the first place.' 